\title{
TFG/NTRK1 Fusion Protein
}

National Cancer Institute

\section{Source}

National Cancer Institute. TFG/NTRK1 Fusion Protein. NCI Thesaurus. Code C99572.

A fusion protein (591 aa, $\sim 66 \mathrm{kDa}$ ) encoded by the TFG/NT RK1 fusion gene. This protein is comprised of the $\mathrm{N}$-terminal half of protein TFG fused to the C-terminus of the high affinity nerve growth factor receptor protein, including an intact tyrosine kinase domain. 